See discussions, stats, and author profiles for this publication at: https://www.researchgate.net/publication/337898865

\title{
Disciplinary Perspectives on Innovation: Management
}

Article in Foundations and Trends ${ }^{\circledast}$ in Entrepreneurship · December 2019

DOI: $10.1561 / 0300000085-3$

CITATIONS

0

2 authors:

James A Cunningham

Northumbria University

113 PUBLICATIONS 1,540 CITATIONS

SEE PROFILE
READS

118

(1) Grace S Walsh
National University of Ireland, Maynooth
12 PUBLICATIONS 192 CITATIONS

SEE PROFILE

Some of the authors of this publication are also working on these related projects:

Economic, Technological and Societal Impacts of Entrepreneurial Ecosystems View project

Call for papers: Entrepreneurial and Innovative Higher Education Ecosystems across the Globe: Theories, Practices and Policy Impacts View project 


\section{Foundations and Trends $^{\circledR}$ in Entrepreneurship Disciplinary Perspectives on Innovation: Management}

Suggested Citation: James A. Cunningham and Grace S. Walsh (2019), "Disciplinary Perspectives on Innovation: Management", Foundations and Trends ${ }^{\circledR}$ in Entrepreneurship: Vol. 15, No. 3-4, pp 391-430. DOI: 10.1561/0300000085-3.

James A. Cunningham Newcastle Business School

UK

Grace S. Walsh

NUI Galway, Ireland 


\section{Contents}

1 Introduction 392

2 Purpose of Innovation 394

3 Definitions of Innovation 396

3.1 Product Innovation . . . . . . . . . . . . . . . . . . . 398

3.2 Process Innovation . . . . . . . . . . . . . . . . 400

3.3 Management Innovation . . . . . . . . . . . . . . . . . . 402

3.4 Business Model Innovation . . . . . . . . . . . . . . . . 403

4 Sources of Innovation and Open Innovation 405

5 Leadership and Innovation 407

6 Organizational Culture and Innovation 409

7 Underground Innovation $\quad 411$

8 Concluding Thoughts and Future Research Avenues 414

$\begin{array}{ll}\text { Acknowledgements } & 417\end{array}$

$\begin{array}{ll}\text { References } & 418\end{array}$ 


\title{
Disciplinary Perspectives on Innovation: Management
}

\author{
James A. Cunningham ${ }^{1}$ and Grace S. Walsh ${ }^{2}$ \\ ${ }^{1}$ Newcastle Business School, UK; \\ james.cunningham@northumbria.ac.uk \\ ${ }^{2}$ NUI Galway, Ireland
}

\begin{abstract}
Management scholars are focusing greater research attention on innovation within firms. Innovation is now viewed as critical for firms to maintain their competitiveness. In this paper our focus is to provide a management disciplinary perspective on innovation. In doing so we consider the purpose of innovation, some definitions of innovation and review some contemporary issues including management innovation, business model innovation, sources of innovation and open innovation. We then consider leadership, organizational culture and underground innovation before we conclude with some future research avenues. We suggest that management scholars should focus future research on innovation on managerial power dynamics, managerial support for underground innovation, managerial characteristics, experiences, leadership styles and behaviors of R\&D managers and innovation failure.
\end{abstract}

Keywords: management; innovation; open innovation; business model innovation.

James A. Cunningham and Grace S. Walsh (2019), "Disciplinary Perspectives on Innovation: Management", Foundations and Trends ${ }^{\circledR}$ in Entrepreneurship: Vol. 15, No. 3-4, pp 391-430. DOI: 10.1561/0300000085-3. 


\section{Introduction}

In recent years there has been a growing trend in the popular business press of highlighting firms that are viewed as innovative. Such innovations may center on the introduction of new firm processes or detail novel products or services that have been brought to market. Other examples focus on firms utilizing innovation to disrupt industries or market segments and in doing so change the rules of competition. This interest in innovation is further compounded by the fact that policy makers are focused on implementing policy instruments that encourage firm level innovation. The adaption of new processes and practices is seen as central to ensuring long-term survival and sustainability. Inside firms, employees are encouraged to be more creative and innovative to support the business strategy of the firm. In turn, firms have adopted new managerial practices and approaches that are designed to encourage employees to contribute new ideas and become part of the internal innovation process. In addition to being involved in innovation ideation, employees have become more directly involved in the planning and execution of innovation within and outside firms. The section focuses on innovation, specifically how it is viewed and empirically studied from the management discipline perspective. 
The section begins with a discussion as to the purpose of innovation before outlining some of popular definitions of the concept. Different aspects of product and process innovation are reviewed in the next sections. Subsequently, management innovation as an extension of organizational innovation is examined, followed by business model innovation and more recent evolving research strands within the management domain. The section then proceeds to highlight the sources of innovation and explores the concept of open innovation. The role of leadership and organization culture is then discussed, followed by an examination of underground innovation. The section concludes with an outline of potential future research avenues. 


\section{Purpose of Innovation}

Innovate or die is one of the main management mantras in relation to firm focused innovation. The simple logic is that if firms and their management teams fail to innovate, then over time the firm will become less competitive and as a result succumb to failure. Contemporary environmental threats from digital based business models and the Internet of Things (IoT) provide new innovation challenges for firms and their management teams (see Cunningham and Whalley, Forthcoming; Nambisan et al., 2017). Within the management discipline and other related disciplinary areas there is a growing body of literature and empirical studies that examine innovation from a "management of innovation" perspective inside firms (see Adams et al., 2006; Brem and Voigt, 2009; Hidalgo and Albors, 2008; Tidd, 2001). For example, Van de Ven (1986) argues that the managing of innovation creates four problems for managers - a human problem, a process problem, a structural problem and a strategic problem - and it is the role of top management teams and general management to effectively manage innovation inside a firm. Such studies over the last three decades have provided management teams with an array of tools and approaches that they can use for the 
management of innovation within their firms (see examples Bitner et al., 2008; Gustafsson et al., 2012; Von Hippel and Katz, 2002). However, there is a lack of universal consensus as to what constitutes management innovation best practice for managers and their firms (Tidd, 2001).

The core purpose of innovation as Johne (1999) states is to: "improve business performance"; it is a key source of firm competitiveness and advantage (Shoham and Fiegenbaum, 2002). Innovation is critical to firm survival (see Banbury and Mitchell, 1995), firm performance (see Lee et al., 2000; Roberts, 1999; Tsai, 2001) and is a source of regenerative entrepreneurship (Walsh and Cunningham, 2017). Damanpour (1991, p. 556) highlights the potential impact of environmental conditions on innovation: "The adoption of innovation is generally intended to contribute to the performance or effectiveness of the adopting organization. Innovation is a means of changing an organization, whether as a response to change in its internal or external environment or as a preemptive action taken to influence an environment." Irrespective of the size of firm, innovation creates ongoing challenges for the firm, its management team and employees. One such challenge for firms and management teams is to mobilize and create a common purpose (see Senge, 1998) that enables innovation inside and outside the firm.

While there is clear evidence detailing how innovation positively impacts on firm performance and supports value creation for current and future customers, the challenge and dilemma for management teams is how innovation can be harnessed effectively for long-term competitive success. Moreover, Cunningham and Harney (2012) argue that innovation provides firms with the basis for competitive differentiation, which is essential to ensuring a sustainable, market-based, competitive position. The innovation strategy and the management of innovation inside a firm are core components of how firms respond and adapt to the external environment. 


\section{3}

\section{Definitions of Innovation}

There are a myriad of definitions of innovation within management studies. One of the seminal definitions of innovation is by Drucker (1985, p. 17) who states: "Innovation is the specific tool of entrepreneurs, the means by which they can exploit change as an opportunity for a different business or a different service. It is capable of being practiced." The application of innovation to different aspects of firms' activities is the focus of Kanter's (1983) definition: "Innovation is the generation, acceptance, and implementation of new ideas, processes and products, or services." Whereas Van de Ven's (1986) centers on four basic factors (new ideas, people, transactions, and institutional contexts) defining innovation as: "the development and implementation of new ideas by people who over time engage in transactions with others within an institutional order."

According to Pfeffer (1994, p. 35) "Innovation and change in almost any arena requires the skill to develop power, and the willingness to employ it to get things accomplished." Some definitions of innovation focus on the creation of new ideas from which different forms of innovation emerge. For instance, Amabile (1988) characterizes innovation as being: "...built on ideas as the basic elements. Organization innovation is the successful implementation of creative ideas within an organization." On 
the other hand, Weick's (1979, p. 252) definition emphasizes "putting new things into old combinations and old combination in new combinations," clearly resonating with Schumpeter's (1934, p. 65-66) definition whereby innovation is: "carrying out of new combinations.... and to produce other things, or the same things by different method, means to combine these materials and forces differently." The types of innovation can be categorized as incremental, architectural and incremental (Burgelman et al., 1996). More contemporary discourse tends to categorize innovation as incremental, radical, sustaining, or disruptive. Over the years key academics have contributed to a narrative of innovation that portrays it as a dichotomous scale; it may be sustaining or disruptive (Christensen, 1997), incremental or breakthrough (Tushman and Anderson, 1986) or described as radical or routine (see Zaltman et al., 1973). Whilst such a dualistic narrative can be powerful in illustrating the broad range of innovative scope, it can also reduce the potential for nuance when discussing less polarized innovations.

In reflecting on these various definitions of innovation it is apparent that there is a core common focus centering on the generation and exploitation of new ideas. These definitions implicitly or explicitly imply that innovation involves change inside the firm in order to realize innovation implementation benefits. Kanter's (1983) definition effectively captures the ideation and implementation aspects of innovation. Idea generation is only the beginning of the innovation journey inside a firm. Following generation, ideas then have to be accepted inside the firm after being tested and validated through internal innovation and managerial processes. Most importantly, these ideas must be accepted in the marketplace by customers - existing or new - this is the ultimate test and measure of success. Kanter (1983) in focusing innovation on process, products or services provides a focal point on where innovation activities can be centered on by firms and their management teams. The challenge for firms is whether they have the capacity, skills and resources to purse all these forms of innovation simultaneously given their differences in relation to complexity, risk, financial returns and market competitive success (as measured by increased market share, profit margins, sales revenue, etc.). 


\subsection{Product Innovation}

Product innovation is when a firm either makes a change(s) to an existing product or service or introduces a new product or service to the marketplace. As Cunningham and Harney (2012, p. 463) describe: "These changes can include developing a totally new product, increasing the functionality of an existing product, or, in the case of a service business, improving the customer experience." Utterback and Abernathy $(1975$, p. 642$)$ define product innovation as "a new technology or combination of technologies introduced commercially to meet a user or market need." They suggest that the three objectives for the firm when engaging in product innovation are - performance maximizing, sales maximizing, or cost minimizing. In a study of firms in the chemical and communication industries, Dougherty (1992), examining interpretative barriers to successful product innovation, found that firm product routines and "departmental thought worlds" inhibit product innovation. To overcome such interpretative barriers Dougherty (1992) suggests that product innovation is not the sole responsibility of the $R \& D$ department but is a collective effort within the firm. Firms should seek to develop appropriate mechanisms across the firm's organizational structure and beyond the firm connect with customers and end users. As Dougherty (1992, p. 195) argues "Innovation is an interpretive process, so the management of innovation must involve the management of the interpretive schemes that shape and frame how people make sense of their work" Kamoche and Cunha (2001) argue that firms need to achieve an appropriate balance between structures and flexibility to support product innovation. Furthermore, Hlavacek and Thompson (1973) found that organizational bureaucracy can also inhibit and constrain product innovation and therefore there is a need for organizations to consider new organizational structures, teams, and processes to overcome this constraint.

The pursuit of product innovation has an impact on firm growth; technological innovation tends to be greater in product than process innovation (see Ornaghi, 2006). Product innovation is a key method for firms to respond to the changing needs of their customers and adapt to the external environment (see Brown and Eisenhardt, 1995; 
Burgelman, 1991). Eisenhardt and Tabrizi (1995, p. 84) argue that "product innovation is a primary way in which firms actually adapt." Adapting to changing market technical conditions is critical (see Schoonhoven et al., 1990), it supports firm survival and enhances market share (Banbury and Mitchell, 1995). According to Cooper (2003) crucial success factors for successful product innovation include a unique superior product, a strong market orientation, and appropriate organizational structures including management support. Additional primary success factors for product innovation are product advantage; proficiency of predevelopment and protocols, in conjunction with the capability to manage controllable and situational factors (see Cooper and Kleinschmidt, 1987). However, in large organizational contexts having cross-functional teams may not yield the desired new product innovation due to task disagreements (see Lovelace et al., 2001). Moreover, for younger firms recruiting talent from more established and competitor firms can be a way of overcoming constraints for product innovation (Rao and Drazin, 2002). To maintain product innovation in a large firm context means going beyond procedures, teams, etc. and it requires, as Dougherty and Hardy (1996, p. 1149) note: "a shift from an anti-innovation system to a pro-innovation one ... provided that senior managers are willing to mobilize the power of meaning for innovation. ... We argue that sustained innovation requires a fundamental shift in the configuration of power in an organization ..." It also requires top management and in particular CEOs to take greater levels of risk and to set a different strategic direction that is distinct from just following competitors (Tang et al., 2018). Internal CEOs tend to more inclined to select bolder product innovation strategies than their external counterparts (see Miller et al., 1982).

Within large-scale firms, product innovation can break or violate established rules, making product innovation illegitimate. However product innovators can overcome this illegitimacy through reframing their activities creatively to ensure they are legitimate (see Dougherty and Heller, 1994). Consequently having an organizational culture that supports product innovation is essential; Jassawalla and Sashittal (2002, p. 52) suggest "a careful analysis of an organization's culture - the deeply held, tacit beliefs and value systems that lie at the core of 
organization thinking and action - and an intimate understanding of its socially constructed fabric rich with stories, rituals and artifacts can be helpful in developing meaningful ways to understand why participants in new-product processes behave the way they do." An organizational culture can also inhibit (Naranjo Valencia et al., 2010) as well as enhance product innovation with national culture having a moderating effect (Evanschitzky et al., 2012).

\subsection{Process Innovation}

Process innovation is internally focused within the firm, where a firm makes changes to how a product is produced or a service delivered, so that it contributes to some aspects of competitive advantage such as higher productivity, increased profitability and margins, and a lower cost base (see Cunningham and Harney, 2012). Process innovation can be pervasive within a firm and has an impact on firm productivity (Vivero, 2002). Typically process innovation is focused on technological aspects of firms' activities (see Pisano, 1997) and can be considered as a second order innovation activity. Utterback and Abernathy (1975, p. 641) describe process innovation: "As a process continues to develop toward states of higher productivity through incremental changes in these factors, a cumulative effect is achieved that significantly alters the overall nature of the process .... As a process develops there may be changes in the internal organization structure, the development of a supplier industry for special materials, and technology based capital goods." Davenport (1993, p. 1) advocates the "application of innovation to key processes" and suggests that process innovation achieves "major reductions in process cost or time, or major improvements in quality, flexibility, service levels or other business objectives." Pursuing process innovation can confer a competitive advantage for a firm (see Reichstein and Salter, 2006). Furthermore, given the current societal push for green sustainable development, Hall and Wagner (2012, p. 184) finds, "that only being a process innovator tends to positively influence environmental performance, whereas being purely a product innovator does not." Thus process innovation can assist firms to reduce emissions, an important sustainability consideration. 
Learning-by-doing is part of the innovation process (see Hatch and Mowery, 1998), which yields some learning curve effects inside the firm. Sources of process innovation come from within and outside the firm. Product innovation can drive new process innovation (Kraft, 1990) and they can be mutually supportive (see Cohen and Klepper, 1996; Damanpour and Gopalakrishnan, 2001). In the case of biopharmaceuticals, Lim et al. (2006) argue that there is an inter linkage between process and product innovation. In a large-scale study of UK manufacturing firms Reichstein and Salter (2006) found that use of suppliers, firm size, and having an R\&D presence supports the likelihood of a firm being a process innovator. Some other factors that contribute to process innovation include firm size (Fritsch and Meschede, 2001; Martinez-Ros, 2000), industry concentration (Cabagnols and Le Bas, 2002), trade secrets, competitor numbers (Baldwin et al., 2002) and external knowledge sources (Rouvinen, 2002). In a study of small food firms, Avermaete et al. (2004) argue that process as well as product innovation are driven by internal capabilities - entrepreneurial characteristics, skills of the workforce and investment in knowledge - and external capabilities - reliance on services and sources of innovation such as: other firms, material and equipment suppliers, customers and contract R\&D. Moreover, Leiponen and Helfat (2010, p. 234), in their study of sources of innovation ideas, set in the Finnish manufacturing sector, concluded that there is an "association between the breadth of technological search, in the form of innovation objectives and knowledge sources, and the innovation success of firms." Furthermore, Reichstein et al. (2008, p. 601) also confirmed that collaborating with suppliers and customers as well having a "broad market orientation" were sources of process and product innovation in the UK construction industry.

Making process innovation part of the organizational routines with the support of the firm's management team is difficult. It is also challenging to extract value and return on investment from process innovation. Ettlie and Reza (1992) identify different mechanisms that firms can use to leverage value from process innovation. They suggest upstream integrating mechanisms such as greater supplier collaborations and downstream mechanisms such as customer alliances to further enhance and sustain process innovation inside a firm. SMEs in particular are very 
reliant on external sources of knowledge for process innovation combined with their ability to absorb this within the firm (Hervas-Oliver et al., 2014). Therefore the openness of SME management teams is essential to allow such firms build the necessary culture and capacity to exploit such external sources of knowledge.

\subsection{Management Innovation}

A research strand emerging from within the management discipline is the development of a focus specifically on management innovation. This is a follow on from organizational innovation (see Boer and During, 2001). Damanpour (2014, p. 1267) defines management innovation as "an innovation type that has been represented by a variety of overlapping terms including administrative, managerial, organizational, social and management innovation." This form of innovation can also influence and drive firm performance and "fuel competitive advantage" (Volberda et al., 2014, p. 1245). Birkinshaw et al. (2008, p. 825) define management innovation as "the invention and implementation of management practice, process, structure, or technique that is new to the state of the art and is intended to further organization goals." They also posit that there are four management innovation perspectives - institutional, fashion, cultural and rational - and they identify the key factors that influence innovation processes. Furthermore, Birkinshaw et al. (2008) also outline a management innovation process framework with four distinct phases of motivation - invention, implementation and theorization and labeling.

Hamel (2006, p. 4) defines management innovation "as a marked departure from traditional management principles, processes, and practices or a departure from customary organizational forms that significantly alters the way the work of management is performed." He suggests that firms and their managers can become management innovators by focusing on a big problem, searching for new principles and taking apart the firm's management orthodoxies. Furthermore, Birkinshaw and Mol (2006, p. 88) argue that: "History shows that management innovation has been a key driver for competitive advantage for many companies. For companies that invest in a capacity for pursuing management innovation 
systematically, the potential returns can be substantial." Moreover, Mol and Birkinshaw (2009), who based their study on nearly 20,000 firms employing more than ten people, showed a positive relationship between management innovation and firm performance. Leadership behavior - transaction or transformational - does influence management innovation (see Vaccaro et al., 2012). Nickell et al. (2013) argue that when firms perform poorly this triggers management innovation with respect to marketing given the threat of potential failure and closure, whilst Wright et al. (2012) highlight the positive role that consultants play in implementing management innovation within firms. For example, in a study of management innovation in Spanish hotels, Nieves and Segarra-Ciprés (2015) found firms' relationships with external change agents had a positive effect on management innovation as well as diffusion of knowledge throughout the firm.

\subsection{Business Model Innovation}

Over the last two decades there has been a growing number of management scholars focusing research efforts on the concept of business model innovation. Similar to innovation it is open to much interpretation by management and other discipline scholars (see Foss and Saebi, 2017; Zott et al., 2011); they have focused on a variety of firm level themes and issues (see Spieth et al., 2014). A core focus of research on business model innovation is on value creation within and outside the firm and as Massa and Tucci (2013, p. 423) note: "It emphasizes a systemic and holistic understanding of how any organization orchestrates its system of activities for value creation.... (this) can include suppliers, partners, distribution channels, and coalitions that extend the company's resources." Similarly Teece (2010, p. 173) emphasizes value creation in their business model definition: "A business model articulates the logic and provides data and other evidence that demonstrates how business creates and delivers value to customers. It also outlines the architecture of revenues, costs, and profits associated with the business enterprise delivering that value." Chesbrough (2007) identified six dimensions of business models that support value creation - value proposition, target market, value chain, revenue mechanism, value network and competitive 
strategy. The narrative and numbers are two critical tests for business models within a firm (Magretta, 2002). Business models in the own right can be a source of innovative disruption within a sector and industry and firms need to be able to create as well as innovate their own business models (Chesbrough, 2010). Moreover, based on an extensive literature review of business models, Zott et al. (2011, p. 21) suggest that: "the business model can be a vehicle for innovation and as well as subject of innovation."

Firms compete against each other using business model innovation (see Casadesus-Masanell and Ricart, 2010) and this can contribute to sustained competitive advantage (see Mitchell and Coles, 2003). Taran et al. (2015, p. 301) suggest that a business model: "is a core enabler of any company's performance." A firm possessing technology is not sufficient in its own right and this can be exploited more effectively for competitive success with an appropriate business model. As Chesbrough (2010, p. 354) notes: "Technology by itself has no single objective value. The economic value of a technology remains latent until it is commercialized in some way via a business model. .... In fact, it is probably true that a mediocre technology pursued within a great business model may be more valuable than a great technology exploited via a mediocre business model." While Gambardella and McGahan (2010, p. 263) argue that "business-model innovation occurs when a firm adopts a novel approach to commercializing its underlying assets." Business model innovation can be created through content, structure or governances (see Amit and Zott, 2012), and according to Matzler et al. (2013, p. 31) "business model innovation results when a company increases customer value and simultaneously creates a new value creation and revenue model that allows the company to capture some of the value created in a new way." The challenge for firms and management teams is how to innovate their own business models, in addition to how, and when, to effectively respond to competitor business model innovation (see Christensen et al., 2016). 


\section{Sources of Innovation and Open Innovation}

One of the key managerial challenges for managers is to understand what are the optimal sources that lead to new innovation and whether they are located inside or outside the firm. Outside sources of innovation categorized by Drucker (2002) are demographics changes, new knowledge and changes in perception, whilst internal sources emerge from process needs, industry changes, incongruities and unexpected occurrences. For large firms, suppliers are key sources of innovation, while for SMEs key sources of innovation are co-workers, employees and professional marketing (see Bommer and Jalajas, 2004). In a study of electronic and software firms in the UK Romijn and Albaladejo (2002) found prior experience, and employee skills internally were important sources of innovation for these firms. Interaction between internal and external sources of innovation can improve the innovativeness of firms. To this end, openness to knowledge-sharing and internal competencies, support firm innovation capabilities and capacity (see Caloghirou et al., 2004). Firms can appropriate external sources of innovation through deploying strategies such as alliances, mergers, acquisitions or all of these (see Hagedoorn and Duysters, 2002). For SMEs, having a wealth of external networks in different domain areas (marketing, technical, manufacturing, etc.) are important sources of innovation along with universities (Rothwell, 1991). 
One of the debates associated with sources of innovation is the question of closed or open innovation. For managers they have to consider the trade-offs between open and closed innovation, at a strategic level (see Almirall and Casadesus-Masanell, 2010) Closed innovation means that a firm uses and relies on its own internal resources and capabilities to create and support whatever form of innovation it is exploring and exploiting. The firm also retains full control over all aspects of the process. In contrast Chesbrough (2006, pp. 36-37) defines open innovation as: "firms commercialize external (as well as internal) ideas by deploying outside (as well as in-house) pathways to the market. Specifically, companies can commercialize internal ideas through channels outside of their current businesses in order to generate value for the organization. At its root, open innovation is based on a landscape of abundant knowledge, which must be used readily if it is to provide value for the company that created it." In essence, open innovation means that firms collaborate to appropriate and exploit the necessary knowledge and array of resources, to support the firm's innovation strategy, in order to enhance and sustain its competitive advantage and market position. Moreover, Chesbrough and Crowther (2006) argue that open innovation can be applied to firms that operate in mature and more traditional industries. Studies have found that open innovation can have beneficial impact on a firm in terms of market success and product development (see Cassiman and Veugelers, 2006 and Leiponen and Helfat, 2010). However, the risk for a firm is that if they become too open this may result in a loss of core competencies and control, which in turn undermines their innovative performance (see Enkel et al., 2009). In pursuing open innovation firms can deploy different processes - outside in, inside out and coupled - (see Gassmann and Enkel, 2004). Combining open innovation with an open strategy means firms can balance value capture and creation in a more effective manner (Chesbrough and Appleyard, 2007). Lichtenthaler and Lichtenthaler (2009) posit knowledge capacities - inventive, absorptive, transformative, connective, innovative and desorptive - in managing open innovation from internal and external sources. Furthermore, firms can pursue open innovation in an offensive manner and posture (Van de Vrande et al., 2009). 


\section{5}

\section{Leadership and Innovation}

How firms compete using innovation is a question of strategy for a firm. At one level it is a straightforward strategic question for top management teams to address. For a firm it is simply how will they use innovation as one of the dimensions to compete effectively in the marketplace, to create the value and differentiation that is demanded by customers (see Cunningham and Harney, 2012). On the other hand, it has complex implications as to how a firm is managed on a day-to-day basis and what type of culture, values, and behaviors are expected to support such as strategic imperative. Within the broad management discipline scholars have explored how innovation can be best supported within a firm. For example, Greve's (2007, p. 24) study of innovation in the shipbuilding sector concluded: "The findings suggest that some organizations build up routines for exploration that will lead them to be overall more innovative than other organizations." Moreover in a study of individual innovative behaviors Scott and Bruce (1994) found that leadership, managerial role expectations, and support for innovation were related to individual innovative behavior. Therefore, firms need to carefully select the type of leaders they hire, who will support their chosen innovation approach. Friedrich et al. (2010, p. 22) suggest: "In addressing the ways in which 
leaders may influence innovation, it becomes evident that organizations desiring specific types of innovation, or innovation in general, should select or develop leaders possessing the appropriate knowledge, skills, and abilities necessary to take these actions."

The leadership of a firm does matter when it comes to innovation (see Mumford and Licuanan, 2004) as well as the individual characteristics of the leader (see Mumford et al., 2003). Leaders and management teams need to put in place incentives and rewards for individuals to participate in the innovation processes inside the firm and ensure these are aligned to their own individual motivations (see Baer et al., 2003). The type of leadership style adopted within a firm has an impact on its innovation capability (see Gumusluoglu and Ilsev, 2009; Jung et al., 2003) and therefore firms need to be highly selective in the recruitment and selection (internal and external) of leaders and managers (see McEntire and Greene-Shortridge, 2011). To support innovation leaders in a meaningful and effective manner requires enabling them to conceptualize and act in their role in new ways. Amabile and Khaire (2008, p. 102) capture what is required as: "The first priority of leadership is to engage the right people, at the right times, to the right degree in creative work. That engagement starts when the leader recasts the role of employees. Rather than simply roll up their sleeves and execute top-down strategy employees must contribute imagination." For transformational leaders, there is a need to articulate a clear vision that sets high expectations; this also contributes to enabling innovation (see Sarros et al., 2008). 


\section{Organizational Culture and Innovation}

Another strand of research within the management discipline has focused on the role of organization culture in supporting and stimulating innovative behavior within a firm. A firm's organization culture can have a pervasive impact throughout a firm, particularly with respect to individual behaviors, norms, and expectations in addition to the routines and processes that support the organizations daily activities. In a meta study of organizational innovation and culture, Büschgens et al. (2013, p. 777 ) conclude that: "A developmental culture, based on the values of flexibility and an external orientation, is most likely to be the form of clan control in innovative organizations." For organizational culture to support this development focus for product innovation, HR systems need to center on training, incentives, and team development (see Lau and Ngo, 2004).

Creating and possessing shared values that all members of a firm are committed to is essential (see Naranjo-Valencia et al., 2011). Providing individual supports to employees (Sarros et al., 2008), organizational learning (Sanz-Valle et al., 2011), supervisory support, and a reward system (see Chandler et al., 2000) are factors that support building and sustaining an organizational innovative culture. Hogan and Coote 
(2014, p. 1618) further outline its importance within the firm as they posit: "Organizational culture shaped by management through organizational values, norms, and artifacts, encourages and supports innovative behaviors. In particular, leadership behaviors such as showing respect for employees (e.g., considering their input into decisions that affect them) and showing an appreciation of employees (e.g., recognizing the contribution of employees towards organizational goals) are crucial." For example Hartmann (2006) developed a study set in the construction sector and found that organizational culture supported innovation and mitigated against new ideas getting lost in the daily operations of a firm. While some studies have highlighted the positive impacts of culture on innovation others have shown that it can also inhibit it (see Dougherty and Heller, 1994; Flynn and Chatman, 2001). The ongoing challenge for management teams is that they need to be attentive to structure, people, and processes and how this influences the organizational culture and innovation capacity and capabilities. Organizations that develop and implement an innovation strategy need to engage and collaborate with a wide variety of individuals and organizations. A strong organization culture is essential and critical given the range of collaborations with individuals and organization. 


\section{Underground Innovation}

For organizations the external environment is becoming more dynamic and disruptive. Customers' needs and preferences are becoming more sophisticated and temporal. In order to adapt effectively and anticipate or lead such disruption, organization need to engage with individuals and organizations that bring very radical and diverse perspectives and expertise. Such an evolution in how organizations and management teams cope and respond to change has lead management scholars to focus empirical attention on what is termed underground innovation and innovators. Mollick (2005, p. 21) describes underground innovators: "These individuals have little regard for the business models that companies have carefully devised to profit from those systems. Instead, they are driven by utility, curiosity and occasionally even anger, bypassing technical and legal safeguards in their drive to explore. Called by different names - hackers, phreakers, crackers and modders, among them - these underground innovators have complex and often antagonistic relationships with the companies whose products they modify. In studying underground innovators Mollick (2005) categorizes them into two groups - elites - who develop new original things from existing systems that we never conceived of before and kiddies - who exploits 
an aspect of existing systems that elites have created. Underground innovators can challenge the core viability, sustainability, and profitability of organizations. The natural instinct for organizations is to defend themselves against these underground innovators rather than embracing them and using their capabilities to contribute to innovation endeavors.

Some management scholars focus on underground innovation by examining skunkworks within an organization, a group whose activities are hidden from management teams (see Kanter, 1989). These activities potentially challenge the internal conventional managerial thinking within an organization. Nevertheless, Fosfuri and Rønde (2009) argue that skunkworks should be deliberately designed to be separate from the rest of the department to maximize innovation. Single and Spurgeon (1996) suggest that having senior management support is essential to exploiting skunkwork activities through a commercialization phase. Well-cited examples of skunkworks in the literature are Steve Jobs and Apple, and Toshiba's development of laptops and word processors (see Abetti, 1997a,b). These skunkworks are hidden from management teams so as to avoid the organizational bureaucracy and control that can limit the creativity and scope of activities of underground innovators. When viable skunkworks projects become recognized officially by an organization and are seen as legitimate they can contribute to organizational profitability (see Abetti, 1999). Oster (2010) concurs that such activities can add to profits and terms refers to it as emergent innovation. In a study of a technology intensive MNC, Criscuolo et al. (2013) describe these individuals and the activities they undertake as bootleg R\&D, which can yield significant innovations for an organization. To encourage individuals who bootleg to disclose their ideas early on, Sakhdari and Bidakhavidi (2016, p. 10) suggest that: “...a manager's relational skills and ability to establish relationships based on mutual trust may motivate employees to reveal their underground ideas." From a managerial perspective underground innovation and innovators challenge organizational norms, routines, behaviors, and orthodoxies. They also challenge existing governance arrangements and managerial authority however this is offset from the potential results of their activities, which can be a source of significant innovation and profitability for organizations. The dilemma for management teams is whether they tolerate 
underground innovators inside the firm and/or collaborate with them outside the firms. Moreover, a further consideration for management teams is whether to enhance individual autonomy and promote such behaviors and activities among their underground innovators. 


\section{8}

\section{Concluding Thoughts and Future Research Avenues}

Innovation can enhance organizational performance but it is also very complex, messy, and comes with its own risks and benefits. For management teams, how to innovate, and what forms of innovation to focus organizational effort on, are critical strategic questions. The different forms of innovation outlined in the section come with their own particular challenges from a managerial perspective. Embedding innovation in the organizational and managerial processes can be challenging and can fundamentally change the managerial power dynamics. This may mean that management teams give their employees more autonomy and freedom to pursue different forms of innovation and some of these may not yield any performance enhancements for the firm. Pursuing innovation shapes the organizational culture of a firm, ideally to the extent that it enables different forms of innovation to flourish with the full support of management - managerial support is essential and critical. With respect to undeground innovation, the challenge for management teams is to decide whether this is supported and at what stage does legitimization begin once potential innovations emerge from underground innovators. Moreover, management teams have to decide whether and how to embrace and leverage underground innovators outside the firm to boost and 
sustain organizational performance. Furthermore, management need to consider whether they adapt their organizational processes to support open innovation and then leverage the sources of innovation that are essential to organizational innovation.

While management scholars have made much progress in understanding innovation within and outside firms there is a need for further research that is relevant to practice as well as contributing new knowledge. An area of future research for management scholars to explore is managerial power and innovation. Different forms of innovation discussed in this section change the managerial power dynamics and enhance employee autonomy. The question then arises, what is the role of managers where the pursance of innovation undermines and challenges traditional managerial power and control dynamics. Bootleg R\&D and skunkworks for example, bring this into sharper focus, but how does open innovation, management innovation, and business model innovation shape and influence managerial power?

Scholars that have focused on management innovation have unearthed very relevant insights for managerial practice as well as contributing original insights. Much more research is needed on this topic. Future studies could focus on different organizational types such as professional service firms, non-governmental organizations, public sector bodies and sectors or industry verticals that are experiencing market and technology convergence, such as the Internet of Things. Future studies could take a psychological perspective of management innovation amongst top management teams in different sectors and organizational types, which would likely yield some insights that could influence managerial practice.

More micro-level and contextualised studies of innovation are needed that use different methodologies. Such future studies using innovative methodologies have the potential to unearth processes and practices with respect to different forms of innovation. Combining micro-level and contextualization have the potential to yield rich insights into the lived daily realities of innovation within organizations and the way in which management teams navigate and exploit innovation to support organizational performance. For example, studies may focus on innovation in settings that have not yet been the focus of any significant 
empirical studies such as police forces, political think-tanks, religious orders, social services etc. Studies focusing on particular sectors such as oil and gas, retail, banking and professional practices should have a strong international comparative dimension.

There is a need for management scholars to focus some empirical attention on the managerial roles that directly or indirectly support organization innovation. This could be effected through examining job titles and roles such a R\&D Manager, Chief Innovation Officer, etc. to better understand the antecedent characteristics and experiences necessary for those in these organizational positions to contribute, in a demostrable manner to organizational innovation performance. How do CEOs and top management teams actually support organization innovation and what approaches do they use to demonstrate this support? What are the leadership styles and behaviors adopted by $R \& D$ managers?

Within the entrepreneurship field there has been a growing focus on entrepreneurial failure and recovery (see Walsh and Cunningham, 2016), however there has been limited research focus on innovation failure (see Van der Panne et al., 2003). Thus, a potentially friutful research avenue for management scholars is the focus on innovation failure from a management perspective. The managerial approaches TMTs and CEOs use to recover and learn from innovation failure would be relevant to practitioners, policy makers, and management scholars alike. Specifically, how does innovation failure shape and influence management power, employee autonomy and organizational strategy and structure?

Finally, there is a real need for management scholars to derive more practice orientated analytical tools and techniques, from their empirical studies, which supports management practice. The techniques supporting business modelling and their design have made it very accessible to individual managers and management teams to bolster their analysis and decision making. Such analytical tools and techniques need to have universal accessibility in order for them to be engaged and adopted by managers. For example, studies of underground innovators and their processes and behaviors could lead to codified knowledge that can be used to generate new analytical tools and techniques. 


\section{Acknowledgements}

The authors wish to acknowledge the support and feedback provided

by Professor Albert N. Link and Professor Mike Wright in developing this section. 


\section{References}

Abetti, P. A. (1997a). "Underground innovation in Japan: The development of Toshiba's word processor and laptop computer". Creativity and Innovation Management. 6(3): 127-139.

Abetti, P. A. (1997b). "The birth and growth of Toshiba's laptop and notebook computers: A case study in Japanese corporate venturing". Journal of Business Venturing. 12(6): 507-529.

Abetti, P. A. (1999). "Underground innovation in USA, Europe, and Japan". In: PICMET'99. Portland International Conference nn Management of Engineering and Technology Proceedings. Vol. 1. Portland, OR, USA: IEEE. 91.

Adams, R., J. Bessant, and R. Phelps (2006). "Innovation management measurement: A review". International Journal of Management Reviews. 8(1): 21-47.

Almirall, E. and R. Casadesus-Masanell (2010). "Open versus closed innovation: A model of discovery and divergence". Academy of Management Review. 35(1): 27-47.

Amabile, T. M. (1988). "A model of creativity and innovation in organizations". Research in Organizational Behavior. 10(1): 123-167.

Amabile, T. M. and M. Khaire (2008). "Your organization could use a bigger dose of creativity". Harvard Business Review. 86(10): 101-109. Amit, R. and C. Zott (2012). "Creating value through business model innovation". MIT Sloan Management Review. 53(3): 41-49. 
Avermaete, T., J. Viaene, E. J. Morgan, E. Pitts, N. Crawford, and D. Mahon (2004). "Determinants of product and process innovation in small food manufacturing firms". Trends in Food Science 8 Technology. 15(10): 474-483.

Baer, M., G. R. Oldham, and A. Cummings (2003). "Rewarding creativity: When does it really matter". The Leadership Quarterly. 14: 569-586.

Baldwin, J., P. Hanel, and D. Sabourin (2002). "Determinants of innovative activity in Canadian manufacturing firms". In: Innovation and Firm Performance. Ed. by A. Kleinknecht and P. Mohnen. London: Palgrave. 86-111.

Banbury, C. M. and W. Mitchell (1995). "The effect of introducing important incremental innovations on market share and business survival". Strategic Management Journal. 16(1): 161-182.

Birkinshaw, J. M. and M. J. Mol (2006). "How management innovation happens". MIT Sloan Management Review. 47(4): 81-88.

Birkinshaw, J., G. Hamel, and M. J. Mol (2008). "Management innovation". Academy of Management Review. 33(4): 825-845.

Bitner, M. J., A. L. Ostrom, and F. N. Morgan (2008). "Service blueprinting: A practical technique for service innovation". California Management Review. 50(3): 66-94.

Boer, H. and W. E. During (2001). "Innovation, what innovation? A comparison between product, process and organisational innovation". International Journal of Technology Management. 22(1-3): 83-107.

Bommer, M. and D. S. Jalajas (2004). "Innovation sources of large and small technology-based firms". IEEE Transactions on Engineering Management. 51(1): 13-18.

Brem, A. and K. I. Voigt (2009). "Integration of market pull and technology push in the corporate front end and innovation managementInsights from the German software industry". Technovation. 29(5): 351-367.

Brown, S. L. and K. M. Eisenhardt (1995). "Product development: Past research, present findings, and future directions". Academy of Management Review. 20(2): 343-378. 
Burgelman, R. A. (1991). "Intraorganizational ecology of strategy makring and organization adaptation: Theory and field research". Organization Science. 2: 239-262.

Burgelman, R. A., M. A. Maidique, and S. C. Wheelwright (1996). Strategic Management of Technology and Innovation. Chicago: Irwin Publishing.

Büschgens, T., A. Bausch, and D. B. Balkin (2013). "Organizational culture and innovation: A meta-analytic review". Journal of Product Innovation Management. 30(4): 763-781.

Cabagnols, A. and C. Le Bas (2002). "Differences in the determinants of product and process innovations: The French case". In: Innovation and Firm Performance. Ed. by A. Kleinknecht and P. Mohnen. London: Palgrave. 112-149.

Caloghirou, Y., I. Kastelli, and A. Tsakanikas (2004). "Internal capabilities and external knowledge sources: Complements or substitutes for innovative performance?" Technovation. 24(1): 29-39.

Casadesus-Masanell, R. and J. E. Ricart (2010). "From strategy to business models and onto tactics". Long Range Planning. 43(2-3): 195-215.

Cassiman, B. and R. Veugelers (2006). "In search of complementarity in innovation strategy: Internal $\mathrm{R} \& \mathrm{D}$ and external knowledge acquisition". Management Science. 52(1): 69-82.

Chandler, G. N., C. Keller, and D. W. Lyon (2000). "Unraveling the determinants and consequences of an innovation-supportive organizational culture". Entrepreneurship Theory and Practice. 25(1): 59-76.

Chesbrough, H. (2007). "Business model innovation: It's not just about technology anymore". Strategy and Leadership. 35(6): 12-17.

Chesbrough, H. (2010). "Business model innovaion: Opportunities and barriers". Long Range Planning. 43(2-3): 354-363.

Chesbrough, H. W. (2006). "The era of open innovation. Managing innovation and change". MIT Sloan Management Review. 127(3): $34-41$.

Chesbrough, H. W. and M. M. Appleyard (2007). "Open innovation and strategy". California Management Review. 50(1): 57-76. 
Chesbrough, H. W. and A. K. Crowther (2006). "Beyond high tech: Early adopters of open innovation in other industries". R\&D Management. 36(3): 229-236.

Christensen, C. (1997). The Innovator's Dilemma: When New Technologies Cause Great Firms to Fail. Harvard Business Review Press.

Christensen, C. M., T. Bartman, and D. Van Bever (2016). "The hard truth about business model innovation". MIT Sloan Management Review. 58(1): 31.

Cohen, W. M. and S. Klepper (1996). "A reprise of size and R\&D". Economic Journal. 106: 925-951.

Cooper, R. G. (2003). "Profitable product innovation: The critical success factors". In: The International Handbook on Innovation. Ed. by L. V. Shavinina. Oxford: Elsevier. 139-157.

Cooper, R. G. and E. J. Kleinschmidt (1987). "New products: What separates winners from losers?" Journal of Product Innovation Management. 4(3): 169-184.

Criscuolo, P., A. Salter, and A. L. Ter Wal (2013). "Going underground: Bootlegging and individual innovative performance". Organization Science. 25(5): 1287-1305.

Cunningham, J. and B. Harney (2012). Strategy and Strategists. Oxford University Press.

Cunningham, J. and J. Whalley (Forthcoming). The Internet of Things and Entrepreneurial Ecosystems: Challenges and Opportunities. Palgrave.

Damanpour, F. (1991). "Organizational innovation: A meta-analysis of effects of determinants and moderators". Academy of Management Journal. 34(3): 555-590.

Damanpour, F. (2014). "Footnotes to research on management innovation". Organization Studies. 35(9): 1265-1285.

Damanpour, F. and S. Gopalakrishnan (2001). "The dynamics of the adoption of product and process innovations in organizations". Journal of Management Studies. 38(1): 45-66.

Davenport, T. H. (1993). Process Innovation: Reengineering Work Through Information Technology. Harvard Business Press.

Dougherty, D. (1992). "Interpretive barriers to successful product innovation in large firms". Organization Science. 3(2): 179-202. 
Dougherty, D. and C. Hardy (1996). "Sustained product innovation in large, mature organizations: Overcoming innovation-to-organization problems". Academy of Management Journal. 39(5): 1120-1153.

Dougherty, D. and T. Heller (1994). "The illegitimacy of successful product innovation in established firms". Organization Science. 5(2): 200-218.

Drucker, P. F. (1985). Innovation and Entrepreneurship. Harper Collins. Drucker, P. F. (2002). "The discipline of innovation". Harvard Business Review. 80: 95-104.

Eisenhardt, K. M. and B. N. Tabrizi (1995). "Accelerating adaptive processes: Product innovation in the global computer industry". Administrative Science Quarterly: 84-110.

Enkel, E., O. Gassmann, and H. Chesbrough (2009). "Open R\&D and open innovation: Exploring the phenomenon". RESD Management. 39(4): 311-316.

Ettlie, J. E. and E. M. Reza (1992). "Organizational integration and process innovation". Academy of Management Journal. 35(4): 795827.

Evanschitzky, H., M. Eisend, R. J. Calantone, and Y. Jiang (2012). "Success factors of product innovation: An updated meta-analysis". Journal of Product Innovation Management. 29: 21-37.

Flynn, F. J. and J. A. Chatman (2001). "Strong cultures and innovation: Oxymoron or opportunity?" In: International Handbook of Organizational Culture and Climate, ed. by C. L. Cooper, S. Cartwright, and P. C. Earley. West Sussex: John Wiley and Sons. 263-287.

Fosfuri, A. and T. Rønde (2009). "Leveraging resistance to change and the skunk works model of innovation". Journal of Economic Behavior \& Organization. 72(1): 274-289.

Foss, N. J. and T. Saebi (2017). "Fifteen years of research on business model innovation: How far have we come, and where should we go?" Journal of Management. 43(1): 200-227.

Friedrich, T. L., M. D. Mumford, B. Vessey, C. K. Beeler, and D. L. Eubanks (2010). "Leading for innovation: Reevaluating leader influences on innovation with regard to innovation type and complexity". International Studies of Management \& Organization. 40(2): 6-29. 
Fritsch, M. and M. Meschede (2001). "Product innovation, process innovation, and size". Review of Industrial Organization. 19(3): 335350 .

Gambardella, A. and A. M. McGahan (2010). "Business-model innovation: General purpose technologies and their implications for industry structure". Long Range Planning. 43(2-3): 262-271.

Gassmann, O. and E. Enkel (2004). "Towards a theory of open innovation: Three core process archetypes". RED Management Conference (RADA, 2004). Lisbon.

Greve, H. R. (2007). "Exploration and exploitation in product innovation". Industrial and Corporate Change. 16(5): 945-975.

Gumusluoglu, L. and A. Ilsev (2009). "Transformational leadership, creativity, and organizational innovation". Journal of Business Research. 62(4): 461-473.

Gustafsson, A., P. Kristensson, and L. Witell (2012). "Customer cocreation in service innovation: A matter of communication?" Journal of Service Management. 23(3): 311-327.

Hagedoorn, J. and G. Duysters (2002). "External sources of innovative capabilities: The preferences for strategic alliances or mergers and acquisitions". Journal of Management Studies. 39(2): 167-188.

Hall, J. and M. Wagner (2012). "Integrating sustainability into firms' processes: Performance effects and the moderating role of business models and innovation". Business Strategy and the Environment. 21(3): 183-196.

Hamel, G. (2006). "The why, what, and how of management innovation". Harvard Business Review. 84(2): 72-84.

Hartmann, A. (2006). "The role of organizational culture in motivating innovative behaviour in construction firms". Construction Innovation. 6(3): 159-172.

Hatch, N. W. and D. C. Mowery (1998). "Process innovation and learning by doing in semiconductor manufacturing". Management Science. 44(11-part-1): 1461-1477.

Hervas-Oliver, J. L., F. Sempere-Ripoll, and C. Boronat-Moll (2014). "Process innovation strategy in SMEs, organizational innovation and performance: A misleading debate?" Small Business Economics. 43(4): 873-886. 
Hidalgo, A. and J. Albors (2008). "Innovation management techniques and tools: A review from theory and practice". RED Management. 38(2): 113-127.

Hlavacek, J. D. and V. A. Thompson (1973). "Bureaucracy and new product innovation". Academy of Management Journal. 16(3): 361372 .

Hogan, S. J. and L. V. Coote (2014). "Organizational culture, innovation, and performance: A test of Schein's model". Journal of Business Research. 67(8): 1609-1621.

Jassawalla, A. R. and H. C. Sashittal (2002). "Cultures that support product-innovation processes". Academy of Management Perspectives. 16(3): 42-54.

Johne, A. (1999). "Using market vision to steer innovation". Technovation. 19(4): 203-207.

Jung, D. I., C. Chow, and A. Wu (2003). "The role of transformational leadership in enhancing organizational innovation: Hypotheses and some preliminary findings". The Leadership Quarterly. 14(4-5): 525544.

Kamoche, K. and M. P. E. Cunha (2001). "Minimal structures: From jazz improvisation to product innovation". Organization Studies. 22(5): 733-764.

Kanter, R. M. (1983). Change Masters. New York: Simon and Schuster.

Kanter, R. M. (1989). "Swimming in newstreams: Mastering innovation dilemas". California Management Review. 31(4): 45.

Kraft, K. (1990). "Are product- and process-innovations independent of each other?" Applied Economics. 22: 1029-1038.

Lau, C. M. and H. Y. Ngo (2004). "The HR system, organizational culture, and product innovation". International Business Review. 13(6): 685-703.

Lee, H., K. G. Smith, C. M. Grimm, and A. Schomburg (2000). "Timing, order and durability of new product advantages with imitation". Strategic Management Journal. 21(1): 23-30.

Leiponen, A. and C. E. Helfat (2010). "Innovation objectives, knowledge sources, and the benefits of breadth". Strategic Management Journal. 31(2): 224-236. 
Lichtenthaler, U. and E. Lichtenthaler (2009). "A capability-based framework for open innovation: Complementing absorptive capacity". Journal of Management Studies. 46(8): 1315-1338.

Lim, L. P., E. Garnsey, and M. Gregory (2006). "Product and process innovation in biopharmaceuticals: A new perspective on development". RED Management. 36: 27-36.

Lovelace, K., D. L. Shapiro, and L. R. Weingart (2001). "Maximizing cross-functional new product teams' innovativeness and constraint adherence: A conflict communications perspective". Academy of Management Journal. 44(4): 779-793.

Magretta, J. (2002). "Why business models matter". Havard Business Review. 80(5): 86-92.

Martinez-Ros, E. (2000). "Explaining the decisions to carry out product and process innovations: The Spanish case". Journal of High Technology Management Research. 10(2): 223-242.

Massa, L. and C. L. Tucci (2013). "Business model innovation". The Oxford Handbook of Innovation Management. 20(18): 420-441.

Matzler, K., F. Bailom, S. Friedrich von den Eichen, and T. Kohler (2013). "Business model innovation: Coffee triumphs for Nespresso". Journal of Business Strategy. 34(2): 30-37.

McEntire, L. E. and T. M. Greene-Shortridge (2011). "Recruiting and selecting leaders for innovation: How to find the right leader". Advances in Developing Human Resources. 13(3): 266-278.

Miller, D., M. F. Kets de Vries, and J. M. Toulouse (1982). "Top executive locus of control and its relationship to strategy-making, structure, and environment". Academy of Management Journal. 25(2): 237-253.

Mitchell, D. and C. Coles (2003). "The ultimate competitive advantage of continuing business model innovation". Journal of Business Strategy. 24(5): 15-21.

Mol, M. J. and J. Birkinshaw (2009). "The sources of management innovation: When firms introduce new management practices". Journal of Business Research. 62(12): 1269-1280.

Mollick, E. (2005). "Tapping into the underground". MIT Sloan Management Review. 46(4): 21. 
Mumford, M. D., M. S. Connelly, and B. Gaddis (2003). "How creative leaders think: Experimental findings and cases". The Leadership Quarterly. 14: 411-432.

Mumford, M. D. and B. Licuanan (2004). "Leading for innovation: Conclusions, issues, and direction". The Leadership Quarterly. 15(1): $163-171$.

Nambisan, S., K. Lyytinen, A. Majchrzak, and M. Song (2017). "Digital Innovation Management: Reinventing innovation management research in a digital world". MIS Quarterly. 41(1): 223-238.

Naranjo Valencia, J. C., R. Sanz Valle, and D. Jiménez Jiménez (2010). "Organizational culture as determinant of product innovation". European Journal of Innovation Management. 13(4): 466-480.

Naranjo-Valencia, J. C., D. Jiménez-Jiménez, and R. Sanz-Valle (2011). "Innovation or imitation? The role of organizational culture". Management Decision. 49(1): 55-72.

Nickell, D., M. Rollins, and K. Hellman (2013). "How to not only survive but thrive during recession: A multi-wave, discovery-oriented study". Journal of Business and Industrial Marketing. 28(5): 455-461.

Nieves, J. and M. Segarra-Ciprés (2015). "Management innovation in the hotel industry". Tourism Management. 46: 51-58.

Ornaghi, C. (2006). "Spillovers in product and process innovation: Evidence from manufacturing firms". International Journal of Industrial Organization. 24(2): 349-380.

Oster, G. (2010). "Characteristics of emergent innovation". Journal of Management Development. 29(6): 565-574.

Pfeffer, J. (1994). Competitive Advantage Through People: Unleashing the Power of the Work Force. Boston, MA: Harvard Business School Press.

Pisano, G. P. (1997). The Development Factory: Unlocking the Potential of Process Innovation. Cambridge, MA: Harvard Business Press.

Rao, H. and R. Drazin (2002). "Overcoming resource constraints on product innovation by recruiting talent from rivals: A study of the mutual fund industry, 1986-1994". Academy of Management Journal. 45(3): 491-507. 
Reichstein, T. and A. Salter (2006). "Investigating the sources of process innovation among UK manufacturing firms". Industrial and Corporate Change. 15(4): 653-682.

Reichstein, T., A. J. Salter, and D. M. Gann (2008). "Break on through: Sources and determinants of product and process innovation among UK construction firms". Industry and Innovation. 15(6): 601-625.

Roberts, P. W. (1999). "Product innovation, product-market competition and persistent profitability in the US pharmaceutical industry". Strategic Management Journal. 20(7): 655-670.

Romijn, H. and M. Albaladejo (2002). "Determinants of innovation capability in small electronics and software firms in southeast England". Research Policy. 31(7): 1053-1067.

Rothwell, R. (1991). "External networking and innovation in small and medium-sized manufacturing firms in Europe". Technovation. 11(2): 93-112.

Rouvinen, P. (2002). "Characteristics of product and process innovators: Some evidence from the Finnish innovation survey". Applied Economics Letters. 9(9): 575-580.

Sakhdari, K. and E. J. Bidakhavidi (2016). "Underground innovation: How to encourage bootlegging employees to disclose their good ideas". Technology Innovation Management Review. 6(3): 5-12.

Sanz-Valle, R., J. C. Naranjo-Valencia, D. Jiménez-Jiménez, and L. Perez-Caballero (2011). "Linking organizational learning with technical innovation and organizational culture". Journal of Knowledge Management. 15(6): 997-1015.

Sarros, J. C., B. K. Cooper, and J. C. Santora (2008). "Building a climate for innovation through transformational leadership and organizational culture". Journal of Leadership and Organizational Studies. 15(2): 145-158.

Schoonhoven, C. B., K. M. Eisenhardt, and K. Lyman (1990). "Speeding products to market: Waiting time to first product introduction in new firms". Administrative Science Quarterly: 177-207.

Schumpeter, J. (1934). The Theory of Economic Development. Cambridge, MA: Harvard University Press. 
Scott, S. G. and R. A. Bruce (1994). "Determinants of innovative behavior: A path model of individual innovation in the workplace". Academy of Management Journal. 37(3): 580-607.

Senge, P. M. (1998). "The practice of innovation". Leader to Leader. $8(9): 16-22$.

Shoham, A. and A. Fiegenbaum (2002). "Competitive determinants of organizational risk-taking attitude: The role of strategy reference points". Management Decision. 40(2): 127-141.

Single, A. W. and W. M. Spurgeon (1996). "Creating and commercializing innovation inside a skunk works". Research-Technology Management. 39(1): 38-41.

Spieth, P., D. Schneckenberg, and J. E. Ricart (2014). "Business model innovation-state of the art and future challenges for the field". $R \mathscr{E} D$ Management. 44(3): 237-247.

Tang, M., G. Walsh, D. Lerner, M. A. Fitza, and Q. Li (2018). "Green innovation, managerial concern and firm performance: An empirical study". Business Strategy and the Environment. 27(1): 39-51.

Taran, Y., H. Boer, and P. Lindgren (2015). "A business model innovation typology". Decision Sciences. 46(2): 301-331.

Teece, D. J. (2010). "Business models, business strategy and innovation". Long Range Planning. 43(2-3): 172-194.

Tidd, J. (2001). "Innovation management in context: Environment, organization and performance". International Journal of Management Reviews. 3(3): 169-183.

Tsai, W. (2001). "Knowledge transfer in intra-organizational networks: Effects of network position and absorptive capacity on buiness unit innovation and performance". Academy of Management Journal. 44(5): 996-1004.

Tushman, M. L. and P. Anderson (1986). "Technological discontinuities and organizational environments". Administrative Science Quarterly. 31(3): 439-465.

Utterback, J. M. and W. J. Abernathy (1975). "A dynamic model of process and product innovation". Omega. 3(6): 639-656. 
Vaccaro, I. G., J. J. Jansen, F. A. Van Den Bosch, and H. W. Volberda (2012). "Management innovation and leadership: The moderating role of organizational size". Journal of Management Studies. 49(1): $28-51$.

Van de Ven, A. H. (1986). "Central problems in the management of innovation". Management Science. 32(5): 590-607.

Van de Vrande, V., J. P. J. de Jong, W. Vanhaverbeke, and M. de Rochemont (2009). "Open innovation in SMEs: Trends, motives and management challenges". Technovation. 29: 423-437.

Van der Panne, G., C. Van Beers, and A. Kleinknecht (2003). "Success and failure of innovation: A literature review". International Journal of Innovation Management. 7(03): 309-338.

Vivero, R. L. (2002). "The impact of process innovations on firm's productivity growth: The case of Spain". Applied Economics. 34: 1007-1016.

Volberda, H. W., F. A. Van Den Bosch, and O. R. Mihalache (2014). "Advancing management innovation: Synthesizing processes, levels of analysis, and change agents". Organization Studies. 35(9): $1245-1264$.

Von Hippel, E. and R. Katz (2002). "Shifting innovation to users via toolkits". Management Science. 48(7): 821-833.

Walsh, G. S. and J. A. Cunningham (2016). "Business failure and entrepreneurship: Emergence, evolution and future research". Foundations and Trends in Entrepreneurship. 12(3): 163-285.

Walsh, G. S. and J. A. Cunningham (2017). "Regenerative failure and attribution: Examining the underlying processes affecting entrepreneurial learning". International Journal of Entrepreneurial Behavior \& Research. 23(4): 688-707.

Weick, K. E. (1979). The Social Psychology of Organizing. McGraw-Hill. Wright, C., A. Sturdy, and N. Wylie (2012). "Management innovation through standardization: Consultants as standardizers of organizational practice". Research Policy. 41(3): 652-662.

Zaltman, G., R. Duncan, and J. Holbeck (1973). Innovation and Organizations. New York: Wiley. 
Zott, C., R. Amit, and L. Massa (2011). "The business model: Recent developments and future research". Journal of Management. 37(4): 1019-1042. 